\title{
ADOPTING SOCIO-DEMOGRAPHIC CHARACTERISTICS IN PROFILING GREEN CONSUMERS: A REVIEW OF HYPOTHESES
}

\author{
Arif Hartono \\ Marketing Lecturer, Management Department, Faculty of Economics \\ Indonesian Islamic University (UII), Yogyakarta \\ E-mail: arif.hartono@fe.uii.ac.id
}

\begin{abstract}
In the last three decades worldwide environmental consciousness has increased dramatically as well as profiling green consumers have gained tremendous attention in the past. Segmenting and targeting markets base on pro-environmental purchase behavior are essential when companies positioning their green products. Socio-demographic characteristics have gained a lot of attention as the key profiling variables. Such characteristics have been employed by many scholars more frequently for the bases of segmenting and profiling green consumers. However, most existing studies of green consumers' socio-demographic were US based. The present article attempts to review the common hypotheses of socio-demographic characteristics in profiling green consumers. The present article reviews five general hypotheses relating to socio-demographics and environmental consciousness of green consumers, namely the gender, age, education level, income, and occupation hypotheses, as well as the theoretical explanation for each hypothesis. Most previous studies tend to have the same conclusion in the gender, age, education level, and income characteristics. Critics to socio-demographic characteristics and a need to conduct green marketing research in Indonesia was also reviewed.
\end{abstract}

Key words: profiling, socio-demographic, green consumer, hypotheses.

\section{INTRODUCTION}

In the last three decades worldwide environmental consciousness has increased dramatically. The increase has had a great impact on consumer behavior; therefore marketers should understand environmental issues and be able to integrate this consideration into an appropriate marketing strategy. Market segmentation simply means dividing the whole of a market into separate homogeneous groups. As suggested by Schlegelmilch et al. (1996) that segmenting and targeting markets base on proenvironmental purchase behavior are essential when companies positioning their green products.

Profiling green consumers have gained tremendous attention in the past (e.g. Chan, K., 1999; Cornwell et al., 1995; Dia- mantopoulos et al. 2003; Jain et al., 2006; Roberts, 1996). A various characteristics have been adopted to profile green consumer segments in the literature of green marketing (Kilbourne et al., 1998). The characteristics include geographic (e.g. Picket et al. 1993; Samdahl et al., 1989), cultural (e.g. Anderson et al. 1974; Murphy et al. 1978; Webster, 1975), personality (e.g. Crosby et al. 1981; Kinnear et al. 1974), and socio-demographic (e.g. Diamantopoulos et al. 2003; Jain et al., 2006; Roberts, 1996).

Socio-demographic characteristics have gained a lot of attention as the key profiling variables (Diamantopoulos et al. 2003). In addition, socio-demographic characteristics have been employed by many scholars more frequently for the bases of 
segmenting and profiling green consumers (Jain \& Kaur, 2006). Previous scholars such as Roberts (1996), Chan (1999), and Diamantopoulos et al. (2003) have conducted a comprehensive review of studies relating impact of the socio-demographic characteristics on green consumers. Diamantopoulos et al. (2003) argue that most existing studies of green consumers' socio-demographic were US based. In Asia, such studies were undertaken since the 1990s. To the best author knowledge, there is relatively few of published literature which examines Indonesian green consumers' characteristics. As a result, there is lack of knowledge into the studies in Indonesia. The most common sociodemographic characteristics that have been employed in the past studies include gender, age, education level, income, and occupation.

Based on above, it might be useful to review existing literature of sociodemographics of green consumers with the hope that many parties in Indonesia such as students, lecturers, and researchers can use such review to conduct study in green marketing field. The present article attempts to review the common hypotheses of sociodemographic characteristics in profiling green consumers. The paper is organized in five sections. The first section defines green marketing and green consumer. The second section provides a brief review of environmental consciousness constructs. The next section examines the common hypotheses and theoretical explanations relating environmental concern and socio-demographic. The fourth section describes critics into sociodemographic characteristics studies. The last section provides a call to conduct research in green marketing area in Indonesia.

\section{DEFINITION OF GREEN MARKETING AND GREEN CONSUMER}

The term "green marketing" has been widely used in popular and professional presses in the past, especially in western world. However, there has been no precise academic effort to define it (Polonsky, 1995). In the present article, the term "green marketing” and "environmental marketing” are used interchangeably. According to (Pride et al., 1993), the term "green marketing" describes an organization's efforts at designing, promoting, pricing and distributing products that will not harm the environment. The number of companies which have produced green products in the world has been incrased (Carson \& Fyfe, 1992). For instance, in the US in 1989, 5\% of all new products launched were identified as green products, while in 1990 the figure increased 10\% (Davis, 1992).

According to Peattie (2001), green consumer has been the central character in the development of green marketing, as businesses attempt to understand and respond to external pressures to improve their environmental performance. However, there is little agreement of the identity and nature of green consumers (Peattie, 2001). The term of "green" in the present article means "pro-environment”, therefore green consumers can be defined as consumers who consider the environment to be important when they purchase products and services.

\section{ENVIRONMENTAL \\ CONSCIOUSNESS' CONSTRUCTS}

Many scholars have studied and adopted the environmental consciousness construct in a wide range of social science fields, such as psychology (e.g. Manrai et al. 1997; Stone et al. 1995), sociology (e.g. Buttel et al., 1978; Macnaghten et al., 1995), environmental studies (e.g. Dunlap \& Van Liere, 1978; Stern et al. 1993, 1995; Thogersen, 1996), business research (e.g. Balderjahn, 1988; McCarty et al., 1994; Shrivastava, 1994; Roberts, 1996; Roberts et al., 1997), and marketing (e.g. Diamantopoulos et al. 2003; Kilbourne et al. 1997). 
A wide range of environmental consciousness constructs have been employed in the past studies. The constructs include "environmental awareness" (Buttell et al., 1978), “environmental knowledge” (Balderjahn, 1988), “environmental concern” (Kinnear et al. 1974; Tognacci et al. 1972; Zimmer et al. 1994), "perceived environmental effectiveness” (Ellen et al. 1991), and "environmental behavior" which is expressed in "recycling behavior" (Anderson et al. 1974; Vining et al., 1990), “conservation behavior” (Geller, 1981; LeonardBarton, 1981), “environmentally friendly purchase behavior” (Davis, 1993; Ottman, 1992; Schwepker et al., 1991) and "ecologically conscious consumer behavior (ECCB)”, (Roberts, 1996). However, there is an existing problem in the past studies; that is only one or select aspects of the environmental consciousness construct have been examined (Schlegelmich et al. 1996; Diamantopoulos et al., 2003). To deal with the problem, Diamantopoulos et al. (2003) recommended environmental consciousness constructs: environmental knowledge, environmental attitude, and environmental behavior.

\section{REVIEW OF HYPOTHESES AND EXPLANATIONS}

In this section the author reviews five general hypotheses relating to sociodemographics and environmental consciousness of green consumers, namely the gender, age, education level, income, and occupation hypotheses, as well as the theoretical explanation for each hypothesis.

\section{The Gender Hypothesis}

The large majority of authors agreed that gender and environmental knowledge have significant relationship. In addition, males tend to have higher and better knowledge about green issues than females. It might be because "males are generally more outgoing, and, hence, more exposed to the environmental information than females" (Jain et al., 2006). Regarding environmental attitude and environmental behavior, a different phenomenon emerge in the past studies, with on the whole females have been found to exhibit more both higher concern and participate in various types of green behavior. Straughan et al. (1999) added that "the development of unique sex roles, skills, and attitudes has led most researchers to argue that women are more likely than men to hold attitudes consistent with the green movement”.

\section{The Age Hypothesis}

With regard to age, there is general belief that age has significant and negative relationship with environmental knowledge (e.g. Anderson et al. 1974; Arcury et al. 1987; Diamantopoulos et al. 2003). In line with the major belief in environmental knowledge, both environmental attitudes (e.g. Diamantopoulos et al. 2003; Scott \& Willits, 1994; Van Liere \& Dunlap, 1981) and environmental behaviors (e.g. Arcury et al. 1987; Diamantopoulos et al. 2003; Samdahl \& Robertson, 1989; Van Liere \& Dunlap, 1981; Zimmer et al. 1994) are significantly and negatively related with age.

Few exceptions were found in the past studies. The studies reported a nonsignificant relationship (e.g. Chan, 1999; Kinnear et al. 1974; Ostman \& Parker, 1987; Shrum et al. 1995) and significantly positive relationship (e.g. Roberts, 1996; Samdahl \& Robertson, 1989) between age and environmental consciousness. In addition, influence of age on environmental behavior was found tend to be country specific (Chan, 1996).

Despite the few exceptions, it can be concluded that generally there is a reverse relationship between the age and environmental knowledge, attitudes, and behaviors. Straughan \& Roberts (1999) argue that possible reason why among the younger consumers have a greater sensitivity towards the 
environmental issues might be they have grown up at a time when the environmental concerns have already become a prominent issue.

\section{The Education Level Hypothesis}

With exceptions of Samdahl \& Robertson (1989) (negative relationships between the education level and both environmental attitudes and behavior) and Arbuthnot \& Lingg (1975) (negative relationships between the education level and selfreported behavior), many studies reveal that there is a positive relationship between education and environmental knowledge (e.g. Arbuthnot et al., 1975; Arcury et al. 1987; Chandler, 1972; Diamantopoulos et al. 2003; Maloney et al., 1973; Maloney et al. 1975; Moore, 1981; Ostman et al., 1987). In term of environmental attitudes, the education level has been found to be positively related with environmental attitudes (e.g. Aaker et al., 1982; Leonard-Barton, 1981; Murphy et al. 1978; Roberts, 1996; Tognacci et al. 1972; Van Liere et al., 1981; Zimmer et al. 1994). With regard to environmental behavior, a positive relationship has been revealed (e.g. Arbuthnot, 1977; Chan, T. S., 1996; Devall, 1970; Harry et al. 1969; Jolibert et al., 1981; Maloney et al., 1973; Ostman et al., 1987; Scott et al., 1994; Webster, 1975). Therefore, it can be concluded that consumers who hold the better education tend to have higher score on all components of environmental consciousness.

The possible reason related to the above findings is "the very nature of ecology with its complex interactions between organisms and environment serves to make its subject matter difficult to understand and assimilate” (Maloney et al. 1975). As a result, the higher-educated person has better understanding of the environmental issues, and then are more concern and more motivated to participate in environmentally responsible behaviors.

\section{The Income Hypothesis}

In regard to income, there is existing general belief that income is positively related to the environmental consciousness, with the reason that the higher income consumers able to pay additional costs associated with supporting the green causes and favoring green products (Straughan et al., 1999). There is relatively few studies report a non-significant impact of income on environmental knowledge (e.g. Buttell et al., 1978), attitudes (e.g., Kassarjian, 1971; Van Liere et al., 1981) and behaviours (Anderson et al. 1974; Antil, 1984; Pickett et al. 1993).

\section{The Occupation Hypothesis}

Compared to socio-demographic characteristics reviewed above, there is no general belief on the occupation, "the results are too diverse to permit any conclusive inference” (Jain \& Kaur, 2006:116). With respect to environmental knowledge, there is no significant relationship between occupation and environmental knowledge (Buttell et al., 1978). Scholars, such as Anderson et al. (1972), and Balderjahn (1988) report a significant relationship between the occupation and the environmental attitudes; whereas a non-significant relationship found on the studies conducted by Kassarjian (1971), Kinnear et al. (1974), Samdahl et al, (1989), Van Liere et al., (1981), and Webster (1975). In term of environmental behavior, inconsistent results also reported in the past studies. Anderson et al. (1974) reported occupation as an important determinant of environmental behavior, while others have found no statistically significant relationship (e.g., Antil, 1984; Roberts, 1996; Samdahl et al., 1989; Straughan et al., 1999; Vining et al., 1990). Having inconsistent result in the past studies, it would be better to create exploratory hypotheses in the future studies. 


\section{Multivariate Analysis}

Past studies of socio-demographic of green consumers tend to perform multiple regression analysis to examine joint effect of all the socio-demographic variables on environmental consciousness constructs. The environmental consciousness variables were used as dependent variables, while the socio-demographics as independent variables. Prior to the multiple regression analysis, several socio-demographic variables have to be converted to dummy (dichotomous) variables.

\section{CRITIQUES ON SOCIO- DEMOGRAPHIC CHARACTERISTICS}

Despite many scholars have employed socio-demographic characteristics in profiling green consumers, critiques to the characteristics exist. Diamantopoulos et al. (2003) argues that it needs to call fresh analysis to the characteristics due to several reasons. First, "many earlier studies failed to investigate the impact of socio-demographic variables on all components of environmental consciousness” (p.466). Second, "many measures of environmental consciousness used in past research have not been subjected to sufficient dimensionality, reliability, and validity tests” (p.466). Third, "many previous studies have been based upon data collected in the 1970s and 1980s. This is a potentially serious problem, as environmental knowledge, attitudes, and behaviors have undergone substantial changes during the last three decades" (p.466). Finally, "the large majority of environmental studies focusing on socio-demographic characteristics are US-based” (p.466).

\section{CALLING TO CONDUCT GREEN MARKETING RESEARCH IN INDONESIA}

Profiles of green consumers have been found differing across countries (e.g. Chan, 1999; Diamantopoulos et al. 2003).
The differences of green consumers' profile and culture contribute to a non-standardized of green marketing strategy throughout the world (Tai \& Tam, 1996), therefore it needs country-specific investigations (Jain et al., 2007).

Taking the critiques and the needs to conduct country-specific investigations into considerations, it might be useful profiling and segmenting Indonesian green consumers. Therefore, findings of the study might be use in adressing the question: who are Indonesian green consumers? To the very best author knowledge, there is relatively few studies into Indonesian green consumers. Findings of such studies, might be provide insight into green marketing. Others topics of green marketing area, such as green marketing strategy, green marketing advertising, green labelling, also can be explored by Indonesian researchers in order to enrich marketing literature in Indonesia.

\section{REFERENCES}

Aaker, D.A. \& Bagozzi, R.P. (1982). Attitudes toward public policy alternatives to reduce air pollution. Journal of Marketing, 42(1), 85-94.

Anderson, W.T., Jr. \& Cunningham, W.H.C. (1972). The socially conscious consumer. Journal of Marketing, 36(3), 23-31.

Anderson, W.T., Jr., Henion, K.E. \& Cox III, E.P. (1974). Socially vs. Ecologically conscious consumers, American Marketing Association Combined ConferenceProceedings, 36 (Spring and Fall), 304-11.

Antil, J.H. (1984). Socially responsible consumers: Profile and implications for publicpolicy. Journal of Macromarketing, 4(2), 18-39.

Arbuthnot, J. (1977). The roles of attitudinal and personality variables in the 
predictionof environmental behavior and knowledge. Environment and Behavior, 9(2), 217-32.

Arbuthnot, J. \& Lingg, S. (1975). A comparison of French and American environmental behaviors, knowledge and attitudes. International Journal of Psychology, 10(4), 275-81.

Arcury, T.A., Scollay, S.J. \& Johnson, T.P. (1987). Sex differences in environmental concern and knowledge: The case of acid rain. Sex Roles, 16(9/10), 463-72.

Balderjahn, I. (1988). Personality variables and environmental attitudes as predictors of ecologically responsible consumption patterns. Journal of Business Research, 17(1), 51-56.

Bohlen, G., Schlegelmilch, B.B. \& Diamantopoulos, A. (1993). Measuring ecological concern: A multiconstruct perspective. Journal of Marketing Management, 9(4), 415430.

Buttell, F.H. \& Flinn, W.L. (1978). The politics of environmental concern: Impacts of party identification and political ideology on environmental attitudes. Environment and Behavior, 10(1), 17-37.

Carson, P. \& Fyfe, A. (1992), “A Canadian retailer's perspective: Loblaw Companies Ltd”, in Charter, $\mathrm{M}$. (Ed.), Greener Marketing, Greenleaf Publishing, Sheffield, pp. 307-10.

Chan, K. (1999). Market segmentation of green consumers in Hong Kong. Journal of International Consumer Marketing, 12(2), 7-24.

Chan, R.Y.K. \& Lau, L.B.Y. (2000). Antecedents of green purchases: A sur- vey in China. Journal of Consumer Marketing, 17(4), 338-357.

Chan, R.Y.K. \& Yam, E. (1995). Green movement in a newly industrializing area: A survey on the attitudes and behavior of the Hong Kong citizens. Journal of Community \& Applied Social Psychology, 5, 273284.

Chan, T.S. (1996). Concerns for environmental issues and consumer purchase preferences: A two-country study. Journal of International Consumer Marketing, 9(1), 43-55.

Cornwell, T.B. \& Schwepker, C.H., Jr. (1995). Ecologically concerned consumers and their product purchases. In M.J. Polonsky and A.T. Mintu-Wimsat (Eds.), Environmental marketing: Strategies, Practice, Theory, and Research, New York: The Haworth Press, Inc.

Crosby, L.A., Gill, G.D., \& Taylor, J.R. (1981). Consumer/Voter Behavior in the Passage of the Michigan Container Law. Journal of Marketing, 45, 19-32

Davis, J. (1992). Ethics and environmental marketing. Journal of Business Ethics, Vol. 11, No. 2, pp. 81-87.

Davis, J.J. (1993). Strategies for environmental advertising. Journal of Consumer Marketing, 10(2), 19-36.

Devall, W.B. (1970). Conservation: An upper-middle class social movement, a replication. Journal of Leisure Research, 3, 123-6.

Diamantopoulos, A., Schlegelmilch, B.B., Sinkovics, R.R. \& Bohlen, G.M. (2003). Can socio-demographics still play a role in profiling green consumers? A review of the evi- 
dence and an empirical investigation. Journal of Business Research, 56(2), 465-80.

Ellen, P.S., Wiener, J.L. \& Cobb-Walgren, C. (1991). The role of perceived consumer effectiveness in motivating environmentally conscious behaviours. Journal of Public Policy and Marketing, 10(2), Fall, 102-17.

Harry, J., Gale, R. \& Hendee, J. (1969). Conservation: An upper-middle class social movement. Journal of Leisure Research, 2, 246-54.

Jain, S.K. \& Kaur, G. (2006). Role of Sociodemographics in Segmenting and Profiling Green Consumers: An Exploratory Study of Consumers in India. Journal of International Consumer Marketing, 18 (3), 107142

Jolibert, A. \& Baumgartner, G. (1981). Toward a definition of the consumerist segment in France. Journal of Consumer Research, 8(June), 114117.

Kassarjian, H.H. (1971). Incorporating ecology into marketing strategy: The case of air pollution. Journal of Marketing, 35(3) July, 61-5.

Kilbourne, W.E. \& Beckmann, S.C. (1998). Review and Critical Assessment of Research on Marketing and the Environment. Journal of Marketing Management, 14 (6), 513-532.

Kinnear, T.C., Taylor, J.R. \& Ahmed, S.A. (1974). Ecologically concerned consumers: Who are they? Journal of Marketing, 38(2) April, 20-24.

Maloney, M.P. \& Ward, M.P. (1973). Ecology: Let's hear from the people: An objective scale for the measurement of ecological attitudes and knowl- edge. American Psychologist, 28(7) July, 583-6.

Manrai LA, Manrai AK, Lascu DN, \& Ryans JK. (1997). How green-claim strength and country disposition affect product evaluation and company image. Psychology Marketing, 14(5):511- 37.

Moore, H.K. (1981). Energy related information-Attitude measures of college-age students, Journal of Environmental Education, 12(1), 30-3.

Murphy, P.E., Kangun, N. \& Locander, W.B. (1978). Environmentally concerned consumers-Racial variations. Journal of Marketing, 42(4), 61-66.

Leonard-Barton, D. (1981). Voluntary simplicity lifestyles and energy conservation. Journal of Consumer Research, 8(3), 243-252.

Ostman, R.E. \& Parker, J.I. (1987). Impact of education, age, newspapers, and television on environmental knowledge, concerns, and behaviours. Journal of Environmental Education, 19(1), 3-9.

Peattie, K. (2001). Golden goose or wild goose? The hunt for the green consumer. Business Strategy and the Environment, 10, pp. 187-199

Pickett, G.M., Kangun, N. \& Grove, S.J. (1993). Is there a general conserving consumer? A public policy concern. Journal of Public Policy and Marketing, 12(2), 234-43.

Polonsky, M.J., (1995). A stakeholder theory approach to designing environmental marketing strategy. Journal of Business and Industrial Marketing, Vol. 10, No. 3, pp. 29-46 
Pride, W.M. \& Ferrell, O.C. (1993), Marketing, 8th ed., Houghton Mifflin, Boston, MA.

Roberts, J.A. (1996). Green consumers in 1990s: Profile and implications for advertising. Journal of Business Research, 36(3), 217-231.

Samdahl, M.D. \& Robertson, R. (1989). Social determinants of environmental concern: Specification and test of the model. Environment and Behavior, 21(1), January, 57-81.

Schlegelmilch, B.B., Bohlen, G.M. \& Diamantopoulos, A. (1996). The link between green purchasing decisions and measures of environmental consciousness. European Journal of Marketing, 30(5), 35-55.

Schwepker, C.H. \& Cornwell, T.B. (1991). An examination of ecologically concerned consumers and their intention to purchase ecologically packaged products. Journal of Public Policy and Marketing, 10(2), Fall, 77-101.

Scott, D. \& Willits, F.K. (1994). Environmental attitudes and behaviour: A Pennsylvania survey. Environment and Behavior, 26(2), March, 239-60.

Shrum, L.J., McCarty, J.A. \& Lowrey, T.M. (1995). Buyer characteristics of the green consumer and their implications for advertising strategy. Journal of Advertising, 24(2), 71-82.

Stern, P.C., Dietz, T. \& Kalof, L. (1993). Value orientations, gender, and environmental concern. Environment and Behavior, 25(3), 322-48.
Straughan, R.D. \& Roberts, J.A. (1999). Environmental segmentation alternatives: A look at green consumer behaviour in the new millennium. Journal of Consumer Marketing, 16(6), 558-575.

Tai, S.H.C. \& Tam, J.L.M. (1996). A comparative study of Chinese consumers in Asian markets-A lifestyle analysis. Journal of International Consumer Marketing. 9(1), 25-42.

Tognacci, L.N., Weigel, R.H., Wideen, M.F. \& Vernon, D.T.A. (1972). Environmental quality: How universal is public concern? Environment and Behavior, 4(1), 73-86.

Thøgersen J. (1996). Recycling and morality: a critical review of the literature. Environment Behavior, 28(4), 536- 58.

Van Liere, K.D. \& Dunlap, R.E. (1981). Environmental concern: Does it make a difference how it's measured? Environment and Behavior, 13(6), 651-76.

Vining, J. \& Ebreo, A. (1990). What makes a recycler? A comparison of recyclers and non-recyclers. Environment and Behavior, 22(1), 55-73.

Webster, F.E. Jr. (1975). Determining the characteristics of the socially conscious consumer. Journal of Consumer Research, 2(3), 188-96.

Zimmer, M.R., Stafford, Thomas F. \& Stafford, M.R. (1994). Green issues dimensions of environmental concern. Journal of Business Research, 30(1), 63-74. 